\title{
PROFITABILITY OF SELECT SAMPLE VENTURE CAPITAL INSTITUTIONS IN INDIA: A COIMPARATIVE ANALYSIS
}

KEY WORDS: Profit, Profitability, Venture Capital

\section{K. Gunasekhar}

\section{Dr. K. Ramakrishnaiah*}

Research Scholar, Department Of Commerce, SVU College of CM\&CS, Sri Venkateswara University,Tirupati, Andhra Pradesh,India.

Retd. Professor, Department Of Commerce, SVU College of CM\&CS, Sri Venkateswara University,Tirupati, Andhra Pradesh, India.

*Corresponding Author

Profit refers to the total income earned by an enterprise during the specific period of time. Ability refers to the earning power or operating performance of the concern in its investment. The compound term profitability refers to the operating efficiency of the enterprise. Profitability is the profit making ability which can be considered as an important factor for perpetual existence of firms. Profitability also maximizes the values of stakeholders as well as investors. Any business enterprise can discharge its obligations to various segments of the society only through earning profit. In this research paper the researcher made an attempt to present the analysis on profitability of select sample venture capital institutions of India and those of abroad operating in India. Profitability ratios considered for the purpose of analysis are earnings before interest and tax to capital employed, profit after tax to shareholders fund and earnings per share.

\section{INTRODUCTION}

The term profitability comprises two words viz., profit and ability. The word 'profit' refers to the total income earned by the enterprise during the specific period of time. The word 'ability' refers to the earning power or operating performance of the concern in its investment. The compound term profitability refers to the operating efficiency of the enterprise. Profit is one of the core objectives of any firm for its long term sustainability and survival. Profitability is an important yardstick for measuring the efficiency of a company to earn profit. Profitability is the net result of all policies and decisions taken by the business undertaking. The growth of any business undertaking depends on its profitability. Profitability also maximizes the values of stakeholders as well as investors. Any business enterprise can discharge its obligations to various segments of the society only through the earnings of profit.

\section{OBJECTIVES OFTHE STUDY}

1. To evaluate the profitability efficiency of select sample venture capital institutions in India.

\section{HYPOTHESIS}

There is no significant difference in the profitability efficiency among the select sample venture capital institutions in India in terms of earnings before interest and tax to capital employed, profit after tax to shareholders fund and earnings pershare.

\section{Ratio of Earnings before Interest and Tax to Capital} Employed

Ratio of earnings before interest and tax to capital employed is a measure of firm's operating performance. To improve profit margin some firms resort to vertical integration for cost reduction and to derive synergistic benefits. The formula that can be used to arrive at the ratio of earnings before and tax to capital employed is:

Ratio of Earnings Before Interest and Tax to Capital Employed $=\frac{E B I T}{\text { Capital Employed }}$

Table No. 01 Ratio of Earnings Before Interest and Tax to Capital Employed of Select Sample Venture Capital Institutions of India and abroad operating in India over a Period of Ten Years from 2007-08 to 2016-17

(In Times)

\begin{tabular}{|c|c|c|c|c|c|}
\hline Year & \begin{tabular}{|c} 
IFCI \\
Venture \\
Capital \\
Funds \\
Limited
\end{tabular} & $\begin{array}{l}\text { APIDC } \\
\text { Venture } \\
\text { Capital } \\
\text { Limited }\end{array}$ & $\begin{array}{l}\text { Canbank } \\
\text { Venture } \\
\text { Capital } \\
\text { Limited }\end{array}$ & $\begin{array}{l}\text { Infrastructure } \\
\text { Leasing and } \\
\text { Financial } \\
\text { Services } \\
\text { Limited }\end{array}$ & $\begin{array}{c}\text { Jacob } \\
\text { Ballas } \\
\text { Capital } \\
\text { India } \\
\text { Private } \\
\text { Limited }\end{array}$ \\
\hline
\end{tabular}

\begin{tabular}{|c|c|c|c|c|c|}
\hline $2007-08$ & 6.00 & 12.21 & 46.10 & 15.64 & 57.81 \\
\hline $2008-09$ & 6.76 & -7.15 & 31.95 & 12.37 & 7.33 \\
\hline $2009-10$ & 6.14 & 59.54 & 24.63 & 9.34 & 8.80 \\
\hline $2010-11$ & 25.07 & 26.25 & 51.78 & 11.66 & 8.64 \\
\hline $2011-12$ & 19.21 & 13.61 & 69.29 & 12.68 & 11.80 \\
\hline $2012-13$ & 17.00 & 2.25 & 50.66 & 13.34 & 11.54 \\
\hline $2013-14$ & 20.79 & 12.48 & 37.23 & 26.86 & 16.54 \\
\hline $2014-15$ & 13.28 & 30.72 & 36.00 & 8.51 & 19.95 \\
\hline $2015-16$ & 12.62 & -7.88 & 24.25 & 10.29 & 22.70 \\
\hline $2016-17$ & 15.99 & -4.16 & 23.31 & 9.48 & 21.65 \\
\hline Mean & $\mathbf{1 4 . 2 9}$ & $\mathbf{1 3 . 7 9}$ & $\mathbf{3 9 . 5 2}$ & $\mathbf{1 3 . 0 2}$ & $\mathbf{1 8 . 6 8}$ \\
\hline SD & $\mathbf{6 . 5 7}$ & $\mathbf{2 0 . 8 2}$ & $\mathbf{1 4 . 8 9}$ & $\mathbf{5 . 3 2}$ & $\mathbf{1 4 . 8 6}$ \\
\hline CV & $\mathbf{4 5 . 9 9}$ & $\mathbf{1 5 1 . 0 4}$ & $\mathbf{3 7 . 6 9}$ & $\mathbf{4 0 . 8 7}$ & $\mathbf{7 9 . 5 8}$ \\
\hline LGR & $\mathbf{6 . 4 3 N S}$ & $\mathbf{- 1 5 . 3 5 * *}$ & $\mathbf{- 4 . 0 5 N S}$ & $\mathbf{- 1 . 2 9 N S}$ & $\mathbf{- 4 . 4 9 N S}$ \\
\hline CGR & $\mathbf{1 0 . 4 2 N S}$ & - & $\mathbf{- 4 . 4 2 N S}$ & $\mathbf{- 2 . 2 2 N S}$ & $\mathbf{3 . 1 3 N S}$ \\
\hline r-value & $\mathbf{0 . 4 2 N S}$ & $\mathbf{- 0 . 3 0 N S}$ & $\mathbf{- 0 . 3 2 N S}$ & $\mathbf{- 0 . 0 9 N S}$ & $\mathbf{- 0 . 1 7 N S}$ \\
\hline
\end{tabular}

Source: Compiled from the Annual Reports of Select Venture Capital Institutions in India from 2007-08 to 2016-17.

Note: ** Significant at 0.01 Level, NS- Not Significant at 0.05 Level

Table 01 portrays the growth in the ratio of earnings before interest and tax to capital employed of select sample venture capital institutions of India and of abroad but operating in India over a period of ten years from 2007-08 to 2016-17. It is understood from table 01 that the growth in the time series data pertaining to the ratio of earnings before and tax to capital employed of select sample venture capital institutions is not in an order rather it fluctuated from time to time. The mean ratio of earnings before interest and tax to capital employed of Canbank Venture Capital Limited is much higher than the mean ratio of earnings before interest and tax to capital employed of Jacob Ballas Capital India Private Limited, IFCI Venture Capital Funds Limited, APIDC Venture Capital Limited and Infrastructure Leasing and Financial Services (IL\&FS) Limited. The growth in the time series data with reference to the ratio of earnings before interest and tax to capital employed of Canbank Venture Capital Limited and IL\&FS Limited and IFCI Venture Capital Funds Limited had been consistent whereas the growth in the time series data relating to the ratio of earnings before interest and tax to capital employed of Jacob Ballas Capital India Private Limited and APIDC Venture Capital Limited was not consistent. The computed values of LGR for the time series data relating to the ratio of earnings before interest and tax to capital employed of IFCI Venture Capital Funds limited was positive but not significant at 5 per cent level of significance whereas the 
computed LGR for the time series data relating to the ratio of earnings before interest and tax to capital employed of APIDC Venture Capital Limited, Canbank Venture Capital Limited, IL\&FS Limited and Jacob Ballas Capital India Private Limited was negative and moreover not significant at 5 per cent level of significance. The CGR computed for the time series data pertaining to IFCI Venture Capital Funds Limited and Jacob Ballas Capital India Private limited was positive. However those values were not significant at 5 per cent level of significance whereas the values of CGR for the time series data relating to Canbank Venture Capital Limited, IL\&FS Limited and Jacob Ballas Capital India Private Limited were negative and moreover are not significant at 5 per cent level of significance. The ' $r$ ' value computed for the time series data belonging to the ratio of earnings before interest and tax to capital employed of IFCI Venture Capital Funds Limited was positive but small. Therefore, the correlation that existed between the years and earnings before interest and tax to capital employed was low and not significant at 5 per cent level of significance whereas the ' $r$ ' values computed for the time series data relating to earnings before interest and tax to capital employed of APIDC Venture Capital Limited, Canbank Venture Capital Limited, IL\&FS Limited and Jacob Ballas Capital India Private Limited were negative and moreover not significant at 5 per cent level of significance. With this on the whole one can easily understand that the financial performance of Canbank Venture Capital Limited, IFCI Venture Capital Funds Limited and Jacob Ballas Capital India Private Limited was satisfactory compared to the financial performance of APIDC Venture Capital Limited in respect of its size of the earnings before interest and tax.

Table No. 01A The results of the Analysis of Variance (ANNOVA) computed for the time series data relating to the ratio of Earnings Before Interest and Tax to Capital Employed of Select Sample Venture Capital Institutions of India and of abroad operating in India over a period of ten years from 2007-08 to 2016-17

\begin{tabular}{|l|c|c|c|c|c|}
\hline $\begin{array}{l}\text { Source of } \\
\text { Variation }\end{array}$ & SS & df & MS & F & P-value \\
\hline Time periods & 1875.503 & 9 & 208.3893 & 0.897897 & $0.540403 \mathrm{NS}$ \\
\hline $\begin{array}{l}\text { Venture Capital } \\
\text { Institutions }\end{array}$ & 4638.97 & 4 & 1546.323 & 6.662717 & $0.00163 * *$ \\
\hline Error & 6266.322 & 36 & 232.086 & & \\
\hline Total & 12780.8 & 49 & & & \\
\hline
\end{tabular}

Note: NS - Not Significant at 0.05 Level, ** Significant at 0.01 Level.

Table 01A shows the results of the analysis of variance (ANNOVA) computed for the time series data relating to the ratio of earnings before interest and tax to capital employed of select sample venture capital institutions in India over a period of ten years from 2007-08 to 2016-17. It is understood from table 01A that there was no significant difference between the time periods, since the given $P$-value (0.540403) was not significant at 0.05 per cent level of significance. The analysis of variance within the venture capital institutions was significant at 0.01 per cent level of significance. The calculated F Value (6.662717) was greater than the F critical value (5.64). Hence the null hypothesis $\left(\mathrm{H}_{\circ}\right)$ is rejected at 0.01 per cent level of significance. Thus it can be inferred that there was significant difference in the earnings before interest and tax to capital employed among the select sample venture capital institutions in India.

\section{RATIO OF PROFIT AFTER TAX TO SHAREHOLDERS FUND}

To work out the profitability of the company from the point of view of shareholders, the ratio of profit after tax to shareholders is calculated. Ratio of profit after tax to shareholders fund shows the extent to which profitability objective is being achieved. The higher the ratio, higher the benefit that goes to the shareholders. The following formula can be used to compute the ratio of profit after tax to shareholders fund:

Ratio of Profit after Tax to Shareholders Fund $=\frac{\text { Profit after Tax }}{\text { Shareholders Fund }} X 100$

Table No. 02 Ratio of Profit after Tax to Shareholders Fund of Select Sample Venture Capital Institutions of India and abroad operating in India over a Period of Ten Years from 2007-08 to 2016-17

(In Per cent)

\begin{tabular}{|c|c|c|c|c|c|}
\hline Year & $\begin{array}{c}\text { IFCI } \\
\text { Venture } \\
\text { Capital } \\
\text { Funds } \\
\text { Limited }\end{array}$ & $\begin{array}{c}\text { APIDC } \\
\text { Venture } \\
\text { Capital } \\
\text { Limited }\end{array}$ & $\begin{array}{c}\text { Canbank } \\
\text { Venture } \\
\text { Capital } \\
\text { Limited }\end{array}$ & $\begin{array}{c}\text { Infrastructure } \\
\text { Leasing and } \\
\text { Financial } \\
\text { Services } \\
\text { Limited }\end{array}$ & $\begin{array}{c}\text { Jacob } \\
\text { Ballas } \\
\text { Capital } \\
\text { India } \\
\text { Private } \\
\text { Limited }\end{array}$ \\
\hline $2007-08$ & 8.06 & 6.05 & 29.36 & 22.98 & 50.81 \\
\hline $2008-09$ & 3.75 & -22.88 & 20.04 & 13.38 & 4.07 \\
\hline $2009-10$ & 2.07 & 41.88 & 15.65 & 7.81 & 6.29 \\
\hline $2010-11$ & 9.69 & 18.44 & 49.06 & 11.08 & 4.73 \\
\hline $2011-12$ & 12.87 & 9.24 & 46.76 & 14.16 & -15.47 \\
\hline $2012-13$ & 12.85 & -2.39 & 34.04 & 12.86 & 7.28 \\
\hline $2013-14$ & 11.68 & 7.47 & 24.54 & 8.27 & 2.16 \\
\hline $2014-15$ & 12.98 & 19.19 & 24.02 & 6.14 & 12.77 \\
\hline $2015-16$ & 2.82 & -9.56 & 13.25 & 4.89 & 14.88 \\
\hline $2016-17$ & 8.96 & -4.57 & 13.09 & 5.96 & 9.63 \\
\hline Mean & $\mathbf{8 . 5 7}$ & $\mathbf{6 . 2 9}$ & $\mathbf{2 6 . 9 8}$ & $\mathbf{1 0 . 7 5}$ & $\mathbf{9 . 7 2}$ \\
\hline SD & $\mathbf{4 . 3 0}$ & $\mathbf{1 7 . 9 1}$ & $\mathbf{1 2 . 9 4}$ & $\mathbf{5 . 4 4}$ & $\mathbf{1 6 . 6 4}$ \\
\hline CV & $\mathbf{5 0 . 1 2}$ & $\mathbf{2 8 4 . 8 4}$ & $\mathbf{4 7 . 9 6}$ & $\mathbf{5 0 . 5 6}$ & $\mathbf{1 7 1 . 2 3}$ \\
\hline LGR & $\mathbf{4 . 3 8 N S}$ & $\mathbf{- 1 5 . 4 5 * *}$ & $\mathbf{- 5 . 3 5 N S}$ & $\mathbf{- 1 3 . 0 0 * *}$ & $\mathbf{- 1 5 . 4 4 * *}$ \\
\hline CGR & $\mathbf{5 . 4 1 N S}$ & - & $\mathbf{- 6 . 1 1 N S}$ & $\mathbf{- 1 2 . 1 4 * *}$ & - \\
\hline r-value & $\mathbf{0 . 2 6 N S}$ & $\mathbf{- 0 . 1 6 N S}$ & $\mathbf{- 0 . 3 3 N S}$ & $\mathbf{- 0 . 7 7 * *}$ & $\mathbf{- 0 . 2 7 N S}$ \\
\hline
\end{tabular}

Source: Compiled from the Annual Reports of Select Venture Capital Institutions in India from 2007-08 to 2016-17.

Note: ** Significant at 0.01 Level, NS- Not Significant at 0.05 Level

Table 02 shows the ratio of profit after tax to shareholders fund of select sample venture capital institutions of India and of abroad operating in India over a period of ten years from 2007-08 to 2016-17. It is understood from table 02 that the ratio of earnings before interest and tax to capital employed of select sample venture capital institutions in India was not steady rather it fluctuated from time to time over the ten year study period. The mean ratio of profit after tax to shareholders fund of Canbank Venture Capital Limited was much higher than the ratio of profit after tax to shareholders fund of IL\&FS Limited, Jacob Ballas Capital India Private Limited, IFCI Venture Capital Funds Limited and APIDC Venture Capital Funds Limited. The growth in the time series data relating to the ratio of profit after tax to shareholders fund of Canbank Venture Capital Limited was consistent since the computed $\mathrm{CV}$ for the time series data relating to the ratio of profit after tax to shareholders fund of Canbank Venture Capital Limited was less than 50 per cent. Whereas the growth in the time series data relating to the ratio of profit after tax to shareholders fund of IFCI Venture Capital Funds Limited, IL\&FS Limited, Jacob Ballas Capital India Private Limited and APIDC Venture Capital Limited was not consistent. The computed value of LGR for the time series data relating to the ratio of profit after tax to shareholders fund of IFCI Venture Capital Funds Limited was positive but not significant at 5 per cent level of significance. The computed value of LGR for the time series data relating to the ratio of profit after tax to shareholders fund of APIDC Venture Capital limited, IL\&FS Limited and Jacob Ballas Capital India Private Limited was negative but significant at 1 per cent level of significance whereas the computed LGR for the time data pertaining to the ratio of profit after tax to shareholders fund of Canbank

|www.worldwidejournals.com $|+|$ 
Venture Capital Limited was also negative and not significant at 5 per cent level of significance. The computed value of CGR for the time series data relating to the ratio of profit after tax to shareholders fund of IFCI Venture Capital Funds Limited was positive but not significant at 5 per cent level of significance. The computed CGR for the said time series data relating to the ratio of profit after tax to shareholders fund of Canbank Venture Capital Limited was negative and not significant at 5 per cent level of significance whereas the computed CGR for the said time series data of IL\&FS Limited was also negative but significant at 1 per cent level of significance. The computed value of ' $r$ ' for the time series data relating to the ratio of profit after tax to shareholders fund of IFCI Venture Capital Funds Limited was positive but very low and therefore not significant at 5 per cent level of significance. The computed ' $r$ ' for the time series data relating to the ratio of profit after tax to shareholders fund of APIDC Venture Capital Limited, Canbank Venture Capital Limited and Jacob Ballas Capital India Private Limited are negative and not significant at 5 per cent level of significance whereas the computed value of ' $r$ ' for the time series data relating to the ratio of profit after tax to shareholders fund of IL\&FS Limited was also negative but significant at 1 per cent level of significance. Keeping the foregoing analysis in view one can infer that the financial performance of Canbank Venture Capital Limited was satisfactory than the financial performance of IFCI Venture Capital Funds Limited, APIDC Venture Capital Limited, IL\&FS Limited and Jacob Ballas Capital India Private Limited.

Table No. 02A The results of the Analysis of Variance (ANNOVA) computed for the time series data relating to the Ratio of Profit after Tax to Shareholders Funds of Select Sample Venture Capital Institutions of India and of abroad operating in India over a period of ten years from 2007-08 to 2016-17

\begin{tabular}{|l|c|c|c|c|c|}
\hline $\begin{array}{l}\text { Source of } \\
\text { Variation }\end{array}$ & SS & df & MS & F & P-value \\
\hline Time periods & 1949.71 & 9 & 216.6344 & 1.124821 & $0.3796 \mathrm{NS}$ \\
\hline $\begin{array}{l}\text { Venture Capital } \\
\text { Institutions }\end{array}$ & 2556.195 & 4 & 852.0651 & 4.424137 & $0.0118^{*}$ \\
\hline Error & 5200.055 & 36 & 192.5946 & & \\
\hline Total & 9705.961 & 49 & & & \\
\hline
\end{tabular}

Note: NS - Not Significant at 0.05 Level, * Significant at 0.05 Level.

Table 02A shows the results of analysis of variance (ANNOVA) of ratio of profit after tax to shareholders funds of select sample venture capital institutions in India over a period of ten years from 2007-08 to 2016-17. It is understood from table $02 \mathrm{~A}$ that there was no significance difference between the time periods, since the given P-value (0.3796) was not significant at 0.05 per cent level of significance. The variance within the venture capital institutions was highly significant at 0.05 per cent level of significance. The calculated $F$ (4.424137) was greater than the critical value F (3.30). Hence the null hypothesis $\left(\mathrm{H}_{\mathrm{o}}\right)$ is rejected at 0.05 per cent level of signifi cance. There was a significance difference among the select sample venture capital Institutions in attaining the quantum of profit out of their business operations.

\section{EARNINGS PER SHARE}

Earnings per share are the profit available to the equity shareholders on a per share basis i.e., the amount that they can get on every share held. It can be calculated by dividing the profit available to the equity shareholders by the number of outstanding shares. The profits available to the ordinary shareholders are represented by the net profits after taxes and preference dividend. The following formula can be used to compute the earnings per share.

$$
\text { Earnings per Share }=\frac{\text { Profit after Tax }}{\text { No. of Equity Shares }}
$$

Table No. 03 Earnings per share of Select Sample Venture Capital Institutions of India and abroad operating in India over a Period of Ten Years from 2007-08 to 2016-17

(Amount in Rs)

\begin{tabular}{|c|c|c|c|c|c|}
\hline Year & $\begin{array}{c}\text { IFCI } \\
\text { Venture } \\
\text { Capital } \\
\text { Funds } \\
\text { Limited }\end{array}$ & $\begin{array}{c}\text { APIDC } \\
\text { Venture } \\
\text { Capital } \\
\text { Limited }\end{array}$ & $\begin{array}{c}\text { Canbank } \\
\text { Venture } \\
\text { Capital } \\
\text { Limited }\end{array}$ & $\begin{array}{c}\text { Infrastructure } \\
\text { Leasing and } \\
\text { Financial } \\
\text { Services } \\
\text { Limited }\end{array}$ & $\begin{array}{c}\text { Jacob } \\
\text { Ballas } \\
\text { Capital } \\
\text { India } \\
\text { Private } \\
\text { Limited }\end{array}$ \\
\hline $2007-08$ & 1.53 & 8.56 & 38.99 & 44.72 & 17.13 \\
\hline $2008-09$ & 0.74 & -26.34 & 31.87 & 28.86 & 1.43 \\
\hline $2009-10$ & 0.82 & 82.95 & 28.41 & 17.53 & 2.50 \\
\hline $2010-11$ & 2.10 & 44.79 & 163.37 & 21.23 & 2.13 \\
\hline $2011-12$ & 3.15 & 24.72 & 282.49 & 30.34 & -5.55 \\
\hline $2012-13$ & 3.43 & -6.24 & 288.00 & 30.44 & 2.82 \\
\hline $2013-14$ & 3.38 & 21.11 & 244.00 & 27.00 & 0.75 \\
\hline $2014-15$ & 4.13 & 67.09 & 277.00 & 17.50 & 4.39 \\
\hline $2015-16$ & 3.45 & -30.49 & 195.24 & 12.26 & 5.37 \\
\hline $2016-17$ & 3.23 & -13.94 & 200.74 & 16.66 & 3.52 \\
\hline Mean & $\mathbf{2 . 6 0}$ & $\mathbf{1 7 . 2 2}$ & $\mathbf{1 7 5 . 0 1}$ & $\mathbf{2 4 . 6 5}$ & $\mathbf{3 . 4 5}$ \\
\hline SD & $\mathbf{1 . 2 1}$ & $\mathbf{3 8 . 6 0}$ & $\mathbf{1 0 6 . 0 2}$ & $\mathbf{9 . 5 6}$ & $\mathbf{5 . 6 5}$ \\
\hline CV & $\mathbf{4 6 . 4 4}$ & $\mathbf{2 2 4 . 1 4}$ & $\mathbf{6 0 . 5 8}$ & $\mathbf{3 8 . 7 8}$ & $\mathbf{1 6 3 . 7 7}$ \\
\hline LGR & $\mathbf{1 2 . 8 2 * *}$ & $-\mathbf{1 4 . 5 2 * *}$ & $\mathbf{1 4 . 1 6 * *}$ & $\mathbf{- 8 . 6 4 * *}$ & $\mathbf{- 1 4 . 2 7 * *}$ \\
\hline CGR & $\mathbf{1 7 . 8 4 * *}$ & - & $\mathbf{2 7 . 4 6 * *}$ & $\mathbf{- 8 . 2 2 * *}$ & - \\
\hline r-value & $\mathbf{0 . 8 3 * *}$ & $\mathbf{- 0 . 1 9 N S}$ & $\mathbf{0 . 7 0 * *}$ & $\mathbf{- 0 . 6 7 * *}$ & $\mathbf{- 0 . 2 6 N S}$ \\
\hline
\end{tabular}

Source: Compiled from the Annual Reports of Select Venture Capital Institutions in India from 2007-08 to 2016-17.

Note: ** Significant at 0.01 Level, NS- Not Significant at 0.05 Level

Table 03 depicts the earnings per share of select sample venture capital institutions of India and abroad operating in India over a period of ten years from 2007-08 to 2016-17. It is understood from table 03 that the growth in the time series data relating to the earnings per share of select sample venture capital institutions operating in India was not steady rather it fluctuated from period to period over the ten year study period. The mean earnings per of Canbank Venture Capital Limited were more than the mean earnings per share of IL\&FS Limited, APIDC Venture Capital Limited, Jacob Ballas Capital India Private limited and IFCI Venture Capital Funds Limited. The growth in the time series data pertaining to the earnings per share of IL\&FS Limited and IFCI Venture Capital Funds Limited was consistent whereas the growth in the time series data relating to the earnings per share of Canbank Venture Capital Limited, Jacob Ballas Capital India Private Limited and APIDC Venture Capital Limited was not consistent since the computed value of $\mathrm{CV}$ for the time series data relating to the earnings per share of said venture capital institutions was more than 50 per cent. The computed LGR for the time series data relating to earnings per share of Canbank Venture Capital Limited and IFCI Venture Capital Funds limited was positive and significant at 1 per cent level of significance. Whereas the LGR values for the time series data relating to earnings per share of APIDC Venture Capital Limited, IL\&FS Limited and Jacob Ballas Capital India Private Limited was negative but they were significant at 1 per cent level of significance. The computed CGR for the time series data relating to earnings per share of Canbank Venture Capital limited and IFCI Venture Capital Funds Limited was positive and much impressive and significant at 1 per cent level of significance whereas the computed CGR for the time series data relating to earnings per share of IL\&FS Limited was negative but significant at 1 per cent level of significance. The computed value of ' $r$ ' for the time series data relating to the earnings per share of IFCI Venture Capital Funds Limited and Canbank Venture Capital Limited was positive and significant at 1 per cent level of significance. The computed value of ' $r$ ' for the time series data relating to the earnings per share of APIDC Venture Capital Limited was negative but 
significant at 1 per cent level of significance whereas the computed value of ' $r$ ' for the time series data relating to earnings per share of IL\&FS Limited was negative but significant at 1 per cent level of significance. This indicates that there existed a high degree of positive correlation between the years and the earnings per share of IFCIVenture Capital Funds Limited. The ratio of profit after tax to total number of equity shares belonging to Canbank Venture Capital Limited was much higher than the ratio of profit after tax to total number of equity shares belong to IL\&FS Limited, APIDC Venture capital limited, Jacob Ballas Capital India Private Limited and IFCIVenture Capital Funds Limited.

Table No. 03A The results of the Analysis of Variance (AN N OVA) computed for the time series data relating to the Ratio of Profit after Tax to Total Number of Equity Shares of Select Sample Venture Capital Institutions of India and of abroad operating in India over a period of ten years from 2007-08 to 2016-17

\begin{tabular}{|l|c|c|c|c|c|}
\hline Source of Variation & SS & df & MS & F & P-value \\
\hline Time periods & 25978.57 & 9 & 2886.508 & 0.868757 & $0.56350 \mathrm{NS}$ \\
\hline $\begin{array}{l}\text { Venture Capital } \\
\text { Institutions }\end{array}$ & 194082.5 & 4 & 64694.17 & 19.47111 & $0.00 * *$ \\
\hline Error & 89709.45 & 36 & 3322.572 & & \\
\hline Total & 309770.5 & 49 & & & \\
\hline
\end{tabular}

Note: NS - Not Significant at 0.05 Level, ** Significant at 0.01 Level.

Table 03A shows the results of the analysis of variance of ratio of profit after tax to total number of equity shares of select sample venture capital institutions in India over a period of ten years from 2007-08 to 2016-17. It is understood from table 03A that there was no significant difference between time periods, as the given P-value (0.56350) was not significant at 0.05 per cent level of significance. The results of the analysis of variance within the venture capital institutions were significant at 0.01 per cent level of significance. The calculated value of $F(19.47111)$ was greater than the table value of $F(5.64)$. Hence the null hypothesis $\left(\mathrm{H}_{\circ}\right)$ is rejected at 0.01 per cent level of significance.

\section{CONCLUSION}

Keeping the foregoing analysis in view one can infer that the financial performance of Canbank Venture Capital Limited had been satisfactory than the financial performance of IFCI Venture Capital Funds Limited, APIDC Venture Capital Limited, IL\&FS Limited and Jacob Ballas Capital India Private Limited.

\section{REFERENCES}

1. Hemalatha. S and Kamalavalli .A.L, "Profitability Analysis of Cement Companies in India", International Jounal of Current Research and Modern Education,Vol.No.3, Issue No. 1,2018,p.303.

2. Dr. Butalal C. Ajmera, "Profitability Analysis of Asian Paints Ltd", Indian Journal of Research,Vol.No. 1, Issue No.3,March 2012,p.94.

3. Zesshan Fareed, Zahid Ali and Farrukh Shahzad, "Determinants of Profitability: Evidence from Power and Enegry Sector", Studia UBB Profitability: Evidence from Power and
Oeconomica,Vol.61, Issue No.3,2016,pp59-78.

4. M. Krishnamoorthi and M. Ramesh,"A Study on Profitability Analysis of Select Sample Steel Companies in India", Asian Journal of Research in Social Sciences and Humanities, Vol. No. II, Issue No. X, Oct, 2012, ISSN No. 22501665.

5. Annual Reports of IFCI venture capital funds limited from 2007-08 to 2016-17.

6. Annual Reports of APIDC venture capital limited from 2007-08 to 2016-17.

7. Annual Reports of Canbank venture capital limited from 2007-08 to 2016-17.

8. Annual Reports of Infrastructure Leasing and Financial Services Limited from 2007-08 to 2016-17.

9. Annual Reports of Jacob Ballas Capital India Private Limited from 2007-08 to 2016-17. 